JUL 301998

Sta.4 58

ENGINEERING DATA TRANSMITTAL

1. EDT 620373

2. To: (Receiving Organization)

Numatec Hanford Corporation

Process

5. Proj./Prog./Dept./Div.:

SNF Projects
3. From: (Originating Organization)

NHC Process Chemistry

6. Design Authority/ Design Agent/Cog. Engr.: D. B. Bechtold
Related EDT No.:

NA

7. Purchase Order No.:

8. Originator Remarks:

Approval/release of attached study is requested.

11. Receiver Remarks: 11A. Design Baseline Document? [] Yes [X] No
NA

9. Equip./Component No.:

NA

10. System/Bldg./Facility: NA

12. Major Assm. Dwg. No.: NA

13. Permit/Permit Application No.: NA

14. Required Response Date: $07 / 17 / 98$

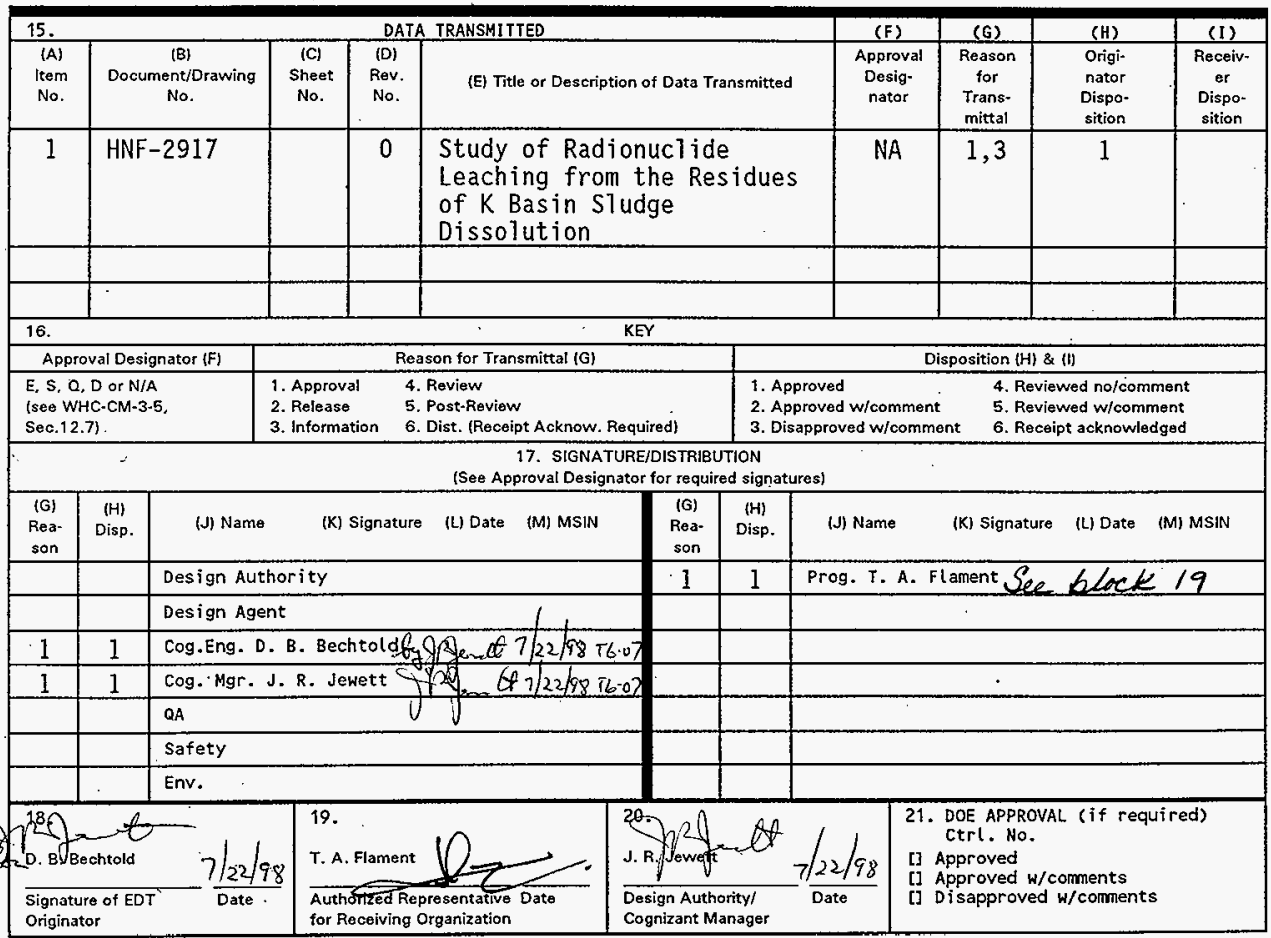

BD-7400-172-2 (05/96) GEF097 
HNF-2917, Rev. 0

\section{Study of Radionuclide Leaching from the Residues of K Basin Sludge Dissolution}

\section{B. Bechtold}

Numatec Hanford Corporation, Richland, WA 99352

U.S. Department of Energy Contract DE-AC06-96RL13200

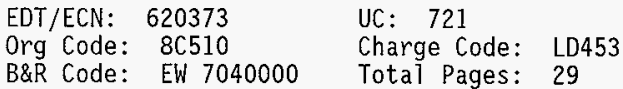

Key Words: Spent Nuclear Fuel, Transuranics, Leaching, Sludge, K Basin, Fuel Storage, Conditioning

Abstract: The sludges remaining in the $K$ Basins after removal of the spent $N$ Reactor nuclear fuel will be conditioned for disposal. After conditioning, an acid-insoluble residue will remain that may require further leaching to properly condition it for disposal. This document presents a literature study to identify and recommend one or more chemical leaching treatments for laboratory testing, based on the likely compositions of the residues. The processes identified are a nitric acid - cerate leach, a silver-catalyzed persulfate leach, a nitrichydrofluoric acid leach, an oxalic - citric acid reactor decontamination leach, a nitric - hydrochloric acid leach, a ammonium fluoride - nitrate leach, and a HEDPA - formaldehydesulfoxylate leach. All processes except the last two are recommended for testing in that order.

IONQUEST is a trademark of Albright \& Wilson

TRADEMARK DISCLAIMER. Reference herein to any specific comercial product, process, or service by trade name, trademark, manufacturer, or otherwise, does not necessarily constitute or imply its endorsement, recomendation, or favoring by the United States Government or any agency thereof or its contractors or subcontractors.

Printed in the United States of America. To obtain copies of this document, contact: Document Control Services, P.0. Box 950, Mailstop H6-08, Richland WA 99352, Phone (509) 372-2420;

Fax (509) 376-4989.
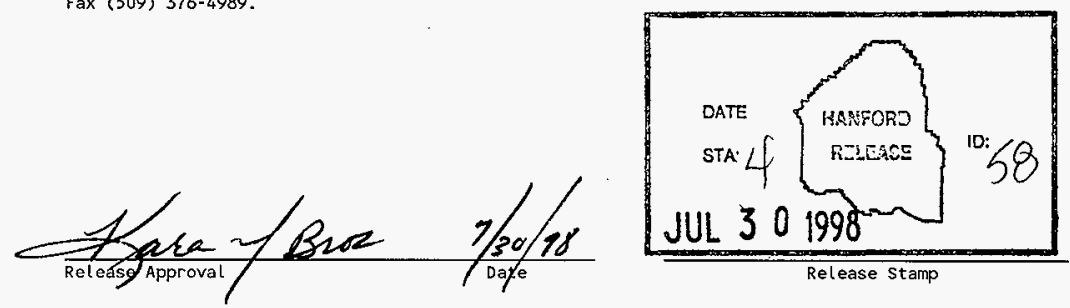

Approved for Public Release 
HNF-2917 Rev. 0

\subsection{INTRODUCTION}

The sludges remaining in the KE and KW fuel storage basins after retrieval of the fuel are likely to contain hydrided uranium and uranium corrosion products, transuranic corrosion products, fission products, steel corrosion products, aluminum corrosion products, Zircaloy pieces, degraded concrete, sand, ion exchange beads and Zeolon ion exchange pellets (Makenas 1996, 1997, 1998). These sludges will have to be disposed of, but no one facility at Hanford will accept them in toto in their current state. The sludge conditioning project will develop the method(s) by which the s7udges will be treated to separate the constituents and direct them towards the appropriate disposal facilities; either ERDF, for particulate, low-level radioactive, non-TRU wastes, or the TWRS tank 241-AW-105, for radioactive but otherwise non$\mathrm{PCB}$, non-reactive waste.

The challenge will be to successfully treat the various sludge components without adding any unacceptable ingredients to the treated product forms (Fowler 1995) (Corriveau 1996), and to treat the sludge safely and economically. Thus far, the general strategy (Pearce 1998) is to consolidate the sludges after fuel washing in the two basins into five streams. Each of these streams will be treated without further mixing. A testing strategy has been issued to develop the details of the general strategy (Flament 1998). Batches of sludge will be stripped of their ion exchange resins and then dissolved in nitric acid (de Lamartinie 1998). The filtered rinse of this dissolution will be treated to reduce its criticality hazard, then neutralized to be disposed of in tank 241-AW-105. It will contain no reactive solid components. On the other hand, the filtered particulate residue that didn't dissolve in nitric acid could possibly contain concentrations of fission and transuranic radionuclides (Carlson 1998) unacceptably high for burial in ERDF.

It is the purpose of this study to look at methods to remove the surviving radionuclides from the residues to the extent that the residue would meet ERDF criteria, and that the rinses would meet TWRS waste compatibility criteria, and recommend one or more methods to be tested for radionuclide leaching effectiveness.

\subsection{BASES FOR ASSUMPTIONS AND CONDITIONS}

A number of issues will affect our formulation of conditions to be met in this project. We begin by considering the restrictions that might be placed on disposing of the products of sludge Teaching, namely the ERDF and TWRS acceptance criteria. Next, we examine what is presently known about the nitric acid dissolution performance and composition of residuals therefrom, to see what sort of additional decontamination 
HNF-2917 Rev. 0

factors (DF) might need to be achieved. Then, we consider the plausible residue types that may be responsible for requiring additional DF's. Finally, we note the waste streams that will be processed and the probable residue types to be found in each.

\subsection{DISPOSAL ACCEPTANCE CONSIDERATIONS}

\subsubsection{ERDF}

ERDF has a list of limits on specific waste constituents, and a sum-of-fractions rule on wastes containing multiple 1 isted constituents (Corriveau 1996). Of greatest importance to the present study are the non-TRU $(<100 \mathrm{nCi} / \mathrm{g})$ limit on transuranics, the $32 \mathrm{Ci} / \mathrm{m}^{3}$ limit on ${ }^{137} \mathrm{Cs}$, and the $0.012 \mathrm{Ci} / \mathrm{m}^{3}$ limit on ${ }^{238} \mathrm{U}$ and its daughters. 0ther limits are not likely to be exceeded by unleached residues.

\subsubsection{TWRS Double Shel1 Tanks}

TWRS defines the acceptability of wastes through a waste transfer compatibility program (Fowler 1995) that sets few clearly defined limits. of that few, however, there are some of relevance to the present program because they make application of traditional iron-dissolution technology problematical. Chloride is limited in tank cars to $0.01 \mathrm{M}$, while phosphate is generally limited to $0.1 \mathrm{M}$. If the chelate content is equivalent to or greater than $10 \mathrm{~g} / \mathrm{L}$ Total Organic Carbon (TOC), then the waste would be considered a chelate waste, which complicates (but does not rule out) the transfer to double shell tanks. Tank 241-AW105 is not currently used as a complexant concentrate tank.

There appears to be no consideration in the TWRS waste compatibility program towards the effect of a waste constituent on future vitrification processes. Certainly the Disposal Program would appreciate not having to deal with more phosphate, sulfate or noble metals than are already present in the tanks, or with graphite. A11 these materials are detrimental to vitrification of tank wastes in glass.

An important point to keep in mind when judging the acceptability of leaching solutions for TWRS disposal is that the leaching solutions are approximately $15 \%$ of the total conditioning stream going to TWRS (de Lamartinie 1998), i.e., there will be a 6.5-fold dilution of the 
HNF-2917 Rev. 0

leaching liquid waste stream that may allow some flexibility in selecting a leaching process.

These considerations are not completely certain, and in the final determination TWRS will have to help decide the acceptability of proposed process wastes for disposal.

\subsection{DECONTAMINATION FACTORS REQUIRED}

Recent testing results of nitric acid dissolution of a variety of KE basin sludges (Flament 1998a) provides data on actual residue compositions summarized in Table 1 below. 
HNF-2917 Rev, 0

\begin{tabular}{|c|c|c|c|c|c|c|c|c|c|c|}
\hline $\begin{array}{c}\text { Sludge and } \\
\text { Residusi }\end{array}$ & $\begin{array}{c}U \\
(\mu g / g)\end{array}$ & $\begin{array}{c}\mathrm{Fe} \\
(\omega \mathrm{g} / \mathrm{g})\end{array}$ & $\begin{array}{c}\mathrm{Ca} \\
(\mu \mathrm{g} / \mathrm{g})\end{array}$ & $\begin{array}{c}\mathrm{Al} \\
(\mu \mathrm{g} / \mathrm{g})\end{array}$ & $\begin{array}{c}\mathrm{Si} \\
(\mu \mathrm{g} / \mathrm{g})\end{array}$ & $\begin{array}{l}137 \mathrm{Cs} \\
(\mu \mathrm{Ci} / \mathrm{g})\end{array}$ & $\begin{array}{l}{ }^{241} \mathrm{Am} \\
(\mu \mathrm{Ci} / \mathrm{g})\end{array}$ & $\begin{array}{l}{ }^{239} \mathrm{Pu} \\
\omega \mathrm{Ci} / g)\end{array}$ & $\begin{array}{l}238_{\mathrm{Pu}} \\
(\mathrm{Ci} / \mathrm{g})\end{array}$ & $\begin{array}{c}\text { TAU } \\
\text { (nCi/g) }\end{array}$ \\
\hline $\begin{array}{l}\text { Canister } \\
\text { Composite }\end{array}$ & $4.22 \times 10^{5}$ & $7.42 \times 10^{3}$ & & $1.14 \times 10^{4}$ & $4.69 \times 10^{3}$ & 498 & 59 & 74.4 & 61 & $1.94 \times 10^{5}$ \\
\hline $\begin{array}{c}\text { Average } \\
\text { Canister } \\
\text { Composite } \\
\text { Residuals }\end{array}$ & $3.89 \times 10^{4}$ & $4.53 \times 10^{4}$ & & $1.77 \times 10^{4}$ & $2.74 \times 10^{5}$ & 81.2 & 6.49 & 17.9 & 7.97 & $3.24 \times 10^{4}$ \\
\hline $\begin{array}{l}\text { Maximum } \\
\text { Canister } \\
\text { Composite } \\
\text { Residuals }\end{array}$ & $5.36 \times 10^{4}$ & $1.81 \times 10^{5}$ & & $2.49 \times 10^{4}$ & $3.56 \times 10^{5}$ & 155 & 9.27 & 26.9 & 10.6 & $4.68 \times 10^{4}$ \\
\hline $\begin{array}{l}\text { Canister \#96-08 } \\
\text { Sludge }\end{array}$ & $4.00 \times 10^{5}$ & $7.30 \times 10^{4}$ & & $7.90 \times 10^{4}$ & & 1180 & 77.3 & 17.4 & 93.5 & $1.88 \times 10^{5}$ \\
\hline $\begin{array}{c}\text { Average } \\
\text { Canister \#96-08 } \\
\text { Residual }\end{array}$ & $2.10 \times 10^{4}$ & $3.14 \times 10^{4}$ & $1.93 \times 10^{4}$ & $4.44 \times 10^{4}$ & $3.09 \times 10^{5}$ & 72.4 & 5.05 & 5.86 & 0.36 & $1.13 \times 10^{4}$ \\
\hline $\begin{array}{c}\text { Maximum } \\
\text { Canister \#96-08. } \\
\text { Residuals }\end{array}$ & $2.29 \times 10^{4}$ & $3.45 \times 10^{4}$ & $2.09 \times 10^{4}$ & $4.54 \times 10^{4}$ & $3.20 \times 10^{5}$ & 77.2 & 5.55 & 6.33 & 0.37 & $1.23 \times 10^{4}$ \\
\hline $\begin{array}{c}\text { Floor/Weasel Pit } \\
\text { Composite }\end{array}$ & $5.41 \times 10^{4}$ & $2.99 \times 10^{5}$ & $4.66 \times 10^{4}$ & $1.13 \times 10^{4}$ & $6.06 \times 10^{4}$ & 825 & 55.3 & 14.1 & 14.3 & $8.36 \times 10^{4}$ \\
\hline $\begin{array}{c}\text { Average } \\
\text { Floor/Weasel Pit } \\
\text { Residuals } \\
\end{array}$ & $2.12 \times 10^{3}$ & $6.66 \times 10^{4}$ & $1.85 \times 10^{4}$ & $5.82 \times 10^{3}$ & $3.07 \times 10^{5}$ & 21.0 & 0.311 & 0.832 & 0.864 & $2.01 \times 10^{3}$ \\
\hline $\begin{array}{l}\text { Maximum } \\
\text { Floor } / \text { Weasel Pit } \\
\text { Residuals }\end{array}$ & $2.42 \times 10^{3}$ & $2.12 \times 10^{5}$ & $2.26 \times 10^{4}$ & $7.58 \times 10^{3}$ & $3.55 \times 10^{5}$ & 64.5 & 0.592 & 2.99 & 3.03 & $6.61 \times 10^{3}$ \\
\hline $\begin{array}{l}\text { Weasel Pit } \\
\# T-20 \text { Sludge }\end{array}$ & $5.84 \times 10^{4}$ & $2.40 \times 10^{5}$ & & $5.30 \times 10^{4}$ & $3.26 \times 10^{5}$ & 550 & 6.54 & 7.98 & 1.27 & $1.58 \times 10^{4}$ \\
\hline $\begin{array}{c}\text { Average } \\
\text { Weasel Pit } \\
\text { \#-20 Residuals }\end{array}$ & $4.60 \times 10^{3}$ & $1.57 \times 10^{5}$ & $6.10 \times 10^{3}$ & $1.77 \times 10^{4}$ & $2.56 \times 10^{5}$ & 45.2 & 0.254 & 0.393 & 0.061 & $7.07 \times 10^{2}$ \\
\hline $\begin{array}{c}\text { Maximum } \\
\text { Weasel Pit } \\
\# T-20 \text { Residuals }\end{array}$ & $5.00 \times 10^{3}$ & $1.92 \times 10^{5}$ & $6.61 \times 10^{3}$ & $1.82 \times 10^{4}$ & $2.89 \times 10^{5}$ & 45.7 & 0.278 & 0.434 & 0.067 & $7.79 \times 10^{2}$ \\
\hline
\end{tabular}

It is found in general that cesium, uranium, plutonium and americium remain above the individual ERDF disposal criteria. Not surprisingly, the residues derived from canister sludge contained the highest concentrations of radionuclides. An approximate, conservative calculation using the maximum values of these test results indicates that a leaching decontamination factor (DF) of 1360 would be needed to bring plutonium below ERDF limits. Americium would require a DF of 273, cesium a DF of 7 , and uranium a DF of 2.2. A DF of 530 would be needed to bring the waste below TRU levels. However, the sum of fractions rule would require a uniform 2060 DF over all these nuclides to bring the worst residue 
HNF-2917 Rev. 0

as a whole into compliance with ERDF limits. A doubling of that factor to approximately 4000 would provide an allowance for process variation.

\subsection{EXPECTED OR POSSIBLE RESIDUE TYPES}

Several types of sludge components that are expected to be insoluble in the nitric acid leach will present varying problems in disposal of the residues. The processes to be selected will depend to a great extent on which of these materials actually contain the radionuclides.

\subsubsection{Grafoil}

The bits of grafoil to be found in KW sludges are expected to be removed in the ion exchange resin separation process and additionally are expected to be inert to actinide absorption. The treatment developed for removing actinides from the resin will be equally effective for washing Grafoil. Hence Grafoil is not considered further.

\subsubsection{Organic Ion Exchange Resin}

A smal1 amount of ion exchange resin can be expected to escape the resin separation process and find its way to the acjd-insoluble residue. Unfortunately, it is possible that only a small amount of resin could carry sufficient actinides into a residue to make it TRU waste. Thankfully, methods for treating that resin for ERDF storage are being considered in detail el sewhere (Dodd 1998). One of those methods may have to be considered when treating residue containing significant amounts of resin.

\subsubsection{Zircaloy-2 Pieces}

Most of the loose Zircaloy-2 cladding generated by the disintegration of $N$ Reactor fuel is expected to be in pieces larger than 0.25 inch, and thus will not be a part of the sludges. However, a small amount of cladding particulate may find its way to sludge residues. It has been shown that N Reactor fuel hulls contain greater than TRU levels of infused actinides (Swanson 1985), which would make them unacceptable for disposat to ERDF. Even after two dissolutions with nitric acid, these hulls contained 420 $\mathrm{nC} \mathrm{i} / \mathrm{g}$ of transuranic alpha emitters, as well as $20 \mu \mathrm{Ci} / \mathrm{g}$ ${ }^{137} \mathrm{Cs}$ and $\mathrm{I} 200 \mu \mathrm{g} / \mathrm{g}$ uranium. Continued treatments with 
HNF-2917 Rev. 0

boiling nitric acid did reduce these values somewhat, but not enough to make the hulls non-TRU. If Zircaloy pieces turn out to be the carriers of significant amounts of actinides or cesium in a residue, then they likely will have to be dissolved in something like a PUREX cladding dissolver solution, because they will equally likely be inert to leaching methods proposed for other residue constituents.

\subsubsection{Active Siliceous Minera]s}

Recent testing at PNNL (Carlson 1998) (Flament 1998a) has shown that nitric acid - insoluble residues from a canister sludge composite are only about $1 \%$ of the total sludge, but that these residues require additional decontamination of the actinides $U, P U$ and $A m$. In addition, it was found that these residues consist mostly of amorphous silica with small amounts of the mineral goethite, or $\mathrm{Fe} 0(\mathrm{OH})$. Thus, it is important to consider whether the actinides could be associated with the silica. In alkali, it has been shown that plutonium (IV) can interact with silica and iron oxides, but not with aluminum oxides (Krot 1998). It is purely speculative to contemplate that this would also hold true in neutral solution, so we have less confidence this is actually occurring.

Another opportunity for actinide-silicon interactions is afforded by the composition of, and corrosion of, the metallic N Reactor Fuel. The fuel was made of uranium alloy 601 (Westinghouse 1988) (Weakley 1979), containing up to 125 ppm silicon among other constituents.

A third opportunity for interaction lies in the KE basin concrete surfaces. The friable nature of the first few millimeters of these surfaces indicates that some corrosion and release of solid, silicate-bearing concrete has taken place. The basin water had a neutral $\mathrm{pH}$, and hence the actinide solubilities were very low (Thomason 1992) But it is still possible that actinides and active silica interacted in solution over two decades' time.

The concrete surfaces of KE basin are friable and have shown a strong affinity for radiocesium (Bechtold 1981). For this reason some concrete constituents along with absorbed cesium can be expected to be found in the residues. In addition, during past operations at KE basin at least one accidenta 1 release of $0.57 \mathrm{~m}^{3}$ of Zeolon 900 ion exchange medium occurred (Hoefer 1997). This medium is strongly cesium specific. 
HNF-2917 Rev. 0

If radionuclides are indeed mineralized with silica, then their release may require a reagent known to react with silica, such as hydrofluoric acid.

\subsubsection{Iron Compounds}

As mentioned above, recent testing has shown that a small amount of goethite, $\mathrm{FeO}(\mathrm{OH})$, survived the nitric acid dissolution step. There has been continuous corrosion of steel and reprecipitation of hydrous iron oxides in both KE and $\mathrm{KW}$ basin since their use as supplemental fuel storage pools began, and it is well known that iron hydroxide precipitation is a good carrier of plutonium. Furthermore, the $\mathrm{N}$ reactor fuel alloy contained up to $400 \mathrm{ppm}$ iron. Hence, there was ample opportunity for actinides to interact with corroding/precipitating iron, and it is possible that actinides could be found in the iron phases of the residues. If so, then reagents that attack iron phases, specifically goethite, would be needed to free these actinides from the residues.

\subsubsection{Actinide-Absorbing Minera]s}

It has been speculated that actinides can be incorporated in a variety of uranium-silicate minerals during oxidative aqueous corrosion of $\mathrm{UO}_{2}$ nuclear fuel (Burns 1997). It has also been shown that certain clay minerals have an affinity for actinides (Eberly 1996). Because uranium oxide has been found in K basin sludges, and because the KE basin concrete walls were produced from local aggregates, and because soil and sand have blown into the basins over the years, we cannot rule out these possibilities as being present in general sludges, and perhaps a portion of them might survive the acid-dissolution to become part of the residue.

\subsubsection{Refractory Actinide Phases}

Technological experience says that difficult-to-dissolve plutonium must be in the form of a refractory oxide $\mathrm{PuO}_{2}$. However, the radionuclides in $\mathrm{K}$ Bas in sludges came from the low-temperature aqueous corrosion of the low-burnup metallic uranium N Reactor fuel, and for that reason we would ordinarily say that very little refractory plutonium oxide should be present (Hashke 1990) (Hashke 1996). However, we shouldn't rule out the possibility entirely, given that the oxidized plutonium has had two decades' time to age towards $\mathrm{PuO}_{2}$. 


\subsubsection{Inert Minerals and Organic Detritus}

Most of the residue is expected to be made up of blow sand, filter sand and soil minerals such as muscovite or other micas that are acid insoluble. The history of $K$ basin operation includes the intrusions of birds and insects into the buildings, leaving the possibility of an occasional feather in the basin. Digestions of $\mathrm{K}$ basin sludges in the past have revealed small amounts of survivable oily deposits in the digestion vessels. Materials like these are not expected to have a particular affinity for actinides or cesium, and therefore will not require direct chemical attack in order to rinse actinides away from them. They may, however, be an interference by consuming the reagents in useless side reactions.

\subsection{WASTE STREAMS}

Each of the five sludge streams should yield residues having unique proportions of the residue types discussed above. There may be an advantage to tailoring the leaching process to each of them as they are conditioned one by one. Their compositions are described here.

\subsubsection{KE Floor/Weasel Pit Sludge with Canister/Fuel Wash Sludge $\leq 250 \mu \mathrm{m}$}

This stream is liable to contain any or all the residue types discussed above except grafoil, but it should consist mostly of inert minerals.

\subsubsection{KE Canister/Fue] Wash S7udge $>250 \mu \mathrm{m}, \leq 0.25$ inch}

This stream may contain all residue types except grafoil, but should be more concentrated relative to the floor sludge in the refractory actinides (if they do exist here), other actinide minerals, and small pieces of Zircaloy.

\subsubsection{KW Floor and Pit Sludge}

Because KW canisters were sealed save for a gas-lock, and the basin walls were painted, the residue from this sludge 


$$
\text { HNF-2917 Rev. } 0
$$

should contain mostly iron corrosion products, aluminum corrosion products, inert minerals and detritus.

\subsubsection{KW Canister/Fuel Wash Sludge $>500 \mu \mathrm{m}, \leq 0.25$ inch}

The residue from this sludge should be very concentrated in the materials that contain actinides, mostly fuel corrosion products. There will also be small amounts of iron corrosion products from the rusted mild steel support shoes of the fuel elements, and aluminum corrosion products from the Mark I canister caps. The residue should be largely free of inert minerals such as sand. Small pieces of grafoit not removed by the resin strip process could be present, as well as could Zircaloy pieces.

\subsubsection{KW Settler Tank Sludge $\leq 500 \mu \mathrm{m}$}

This sludge should come mostly from inside the KW canisters, and therefore be very much like the wash sludge above, except perhaps containing less Zircaloy and grafoj1.

\subsection{PROCESSING ALTERNATIVES IDENTIFIED}

Based on the likely or possible residue types, there do exist laboratory technologies to free the radionuclides from each of them with high certainty. For the soil-like minerais containing iron and inert sand, mixtures of nitric and hydrochloric acids with small amounts of hydrofluoric acid are normally used to leach actinides away for analysis (Catlow 1997) (Bechtold 1994) (Bock 1979). For refractory actinides possibly embedded in siliceous or other minerals, there exist fusions with alkali (Schulz 1991) (Makenas 1998) (Bock 1979) or other total dissolution methods (Byers 1974) involving hydrofluorination, KF and pyrosulfate fusions to completely dissolve minerals. For Zircaloy-2, there is the PUREX decladding solvent, an aqueous $\mathrm{NH}_{4} \mathrm{~F}-\mathrm{NH}_{4} \mathrm{NO}_{3}$ solution.

However, most of these technologies are viewed on a processing scale as severe, corrosive to equipment, hazardous, time-consuming and producing waste difficult to dispose of. It is preferred to find alternatives that may accomplish the radionuclide dissolution by selective leaching without resorting to complete consumption of the residues.

After sorting through many possibilities we find there are a number of practical methods available whose effectiveness is promising, whose effectiveness can be easily verified if necessary by simple laboratory tests, and whose waste streams can be made acceptable to TWRS and ERDF. However, they are not universal. Each practical alternative is proposed 


\section{HNF-2917 Rev. 0}

for a specific residue type, and it will have reduced effectiveness towards other waste types. The ultimate choices will depend on which waste type happens to be predominant.

These more practical alternatives for leaching the residues are summarized in Table 2, and they are individually discussed below. After a discussion of the alternatives will come a section on logical recommendations. 
HNF-2917 Rev. 0

\begin{tabular}{|c|c|c|c|c|c|c|c|c|}
\hline \multirow[t]{2}{*}{ Leaching Process } & \multicolumn{8}{|c|}{ Residue Type } \\
\hline & $\begin{array}{l}\text { Refractory } \\
\text { Actinides }\end{array}$ & Active Silicates & $\begin{array}{l}\text { Other Actinide } \\
\text { Minerals }\end{array}$ & $\mathrm{FeO}(\mathrm{OH})$ & $\begin{array}{l}\text { Inert Minerals } \\
\text { and Organics }\end{array}$ & $\begin{array}{l}\text { Organic lon } \\
\text { Exchange } \\
\text { Resin }\end{array}$ & Grafoil & Zircaloy \\
\hline $\begin{array}{l}\mathrm{Ce}(\mathrm{IV}) \mathrm{O} .4 \mathrm{M} \\
\mathrm{HNO}_{3} 6 \mathrm{M} \\
\mathrm{T}=60-90^{\circ} \mathrm{C} \\
\mathrm{t}=2 \mathrm{hr}\end{array}$ & $\begin{array}{l}\text { Effective } \\
\text { Not Corrosive } \\
\text { TWRS, ERDF } \\
\text { compatible }\end{array}$ & $\begin{array}{l}\text { Possibly Effective } \\
\text { for } \mathrm{PuO}_{2} \text { in Silica }\end{array}$ & Possibly Effective & Not Effective & $\begin{array}{l}\text { Effective as } \\
\text { Rinse Only } \\
\text { Organics will } \\
\text { consume } \\
\text { reagent. }\end{array}$ & $\begin{array}{l}\text { Effective } \\
\text { but } \\
\text { Consumes } \\
\text { Reagent }\end{array}$ & $\begin{array}{l}\text { Effective } \\
\text { as Rinse } \\
\text { Only }\end{array}$ & $\begin{array}{l}\text { Effective ss } \\
\text { Rinse Only } \\
\text { Not Effective } \\
\text { for Infused } \\
\text { Nuelides }\end{array}$ \\
\hline $\begin{array}{l}\mathrm{K}_{2} \mathrm{~S}_{2} \mathrm{O}_{8}=0.5 \mathrm{M} \\
\mathrm{AgNO}_{3}=0.2 \mathrm{M} \\
\mathrm{HNO}_{3}=3 \mathrm{M} \\
\mathrm{T}=\mathrm{ambient} \\
\mathrm{t}=2 \mathrm{hr} .\end{array}$ & Effective & $\begin{array}{l}\text { Possibly Effective } \\
\text { for PuO }{ }_{2} \text { in Silica }\end{array}$ & Possibly Effective & $\begin{array}{l}\text { Only Slight } \\
\text { Effectiveness } \\
\text { through } \mathrm{H}_{2} \mathrm{SO}_{4} \\
\text { generation }\end{array}$ & $\begin{array}{l}\text { Effective as } \\
\text { Rinse Only }\end{array}$ & $\begin{array}{l}\text { Not } \\
\text { Effective }\end{array}$ & $\begin{array}{l}\text { Effective } \\
\text { as Rinse } \\
\text { Only }\end{array}$ & $\begin{array}{l}\text { Effective as } \\
\text { Rinse Only } \\
\text { Not Effective } \\
\text { for Infused } \\
\text { Nuclides } \\
\end{array}$ \\
\hline $\begin{array}{l}\mathrm{HNO}_{3}=6 \mathrm{M} \\
\mathrm{HF}=0.3 \mathrm{M} \\
T=60-90^{\circ} \mathrm{C} \\
t=2 \mathrm{hr} .\end{array}$ & Effective & $\begin{array}{l}\text { Effective } \\
\text { Corrosive to } \\
\text { Equipment } \\
\text { Requires Offgas } \\
\text { Treatment }\end{array}$ & Effective & Not Effective & $\begin{array}{l}\text { Effective as } \\
\text { Rinse Only } \\
\text { but } \\
\text { Consumes } \\
\text { Reagent }\end{array}$ & $\begin{array}{l}\text { Not } \\
\text { Effective }\end{array}$ & $\begin{array}{l}\text { Effective } \\
\text { as Rinse } \\
\text { Only }\end{array}$ & $\begin{array}{l}\text { Effective as } \\
\text { Rinss Only } \\
\\
\text { Not Effective } \\
\text { for Infused } \\
\text { Nuclides }\end{array}$ \\
\hline $\begin{array}{l}\text { "CITROX": } \\
\text { Oxalic Acid }=0.16 \mathrm{M} \\
\text { Citric Acid }=0.3 \mathrm{M} \\
T=80-100^{\circ} \mathrm{C} \\
\mathrm{t}=2 \mathrm{hr} .\end{array}$ & Not Effective & Not Effective & Not Effective & $\begin{array}{l}\text { Effective[?] } \\
\text { May Require } \\
\text { Waste Organic } \\
\text { Destruction }\end{array}$ & $\begin{array}{l}\text { Effective as } \\
\text { Rinse Only }\end{array}$ & $\begin{array}{l}\text { Partially } \\
\text { Effective }\end{array}$ & $\begin{array}{l}\text { Effective } \\
\text { as Rinse } \\
\text { Only }\end{array}$ & $\begin{array}{l}\text { Effective as } \\
\text { Rinse Only } \\
\text { Not Effective } \\
\text { for Infused } \\
\text { Nuclides } \\
\end{array}$ \\
\hline $\begin{array}{l}\mathrm{HNO}_{3}=5 \mathrm{M} \\
\mathrm{HCl}=0.3 \mathrm{M} \\
\mathrm{T}=60-100^{\circ} \mathrm{C} \\
\mathrm{t}=2 \mathrm{hr} .\end{array}$ & Not Effective & Not Effective & Possibly Effective & $\begin{array}{l}\text { Effective } \\
\text { Waste Not } \\
\text { Acceptable to } \\
\text { TWRS without } \\
\text { Treatment } \\
\text { Corrosive to } \\
\text { Equipment }\end{array}$ & $\begin{array}{l}\text { Possibly } \\
\text { Effective }\end{array}$ & $\begin{array}{l}\text { Not } \\
\text { Effective }\end{array}$ & $\begin{array}{l}\text { Effective } \\
\text { as Rinae } \\
\text { Only }\end{array}$ & $\begin{array}{l}\text { Effective as } \\
\text { Rinse Only } \\
\text { Not Effective } \\
\text { for Infused } \\
\text { Nuclides }\end{array}$ \\
\hline $\begin{array}{l}\mathrm{NH}_{4} \mathrm{~F}=5.5 \mathrm{M} \\
\mathrm{NH}_{4} \mathrm{NO}_{3}=0.5 \mathrm{M} \\
\mathrm{T}=\text { Boiling } \\
\mathrm{t}=6 \mathrm{hr} .\end{array}$ & Not Effective & Not Effective & Not Effective & Not Effective & $\begin{array}{l}\text { Effectivo as } \\
\text { Rinse Only }\end{array}$ & $\begin{array}{l}\text { Not } \\
\text { Effective }\end{array}$ & $\begin{array}{l}\text { Effective } \\
\text { as Rinse } \\
\text { Only }\end{array}$ & $\begin{array}{l}\text { Effective } \\
\text { Requires } \\
\text { Waste } \mathrm{F}^{-} \\
\text {Neutralization, } \\
\mathrm{H}_{2}, \mathrm{NH}_{3} \\
\text { offgas }\end{array}$ \\
\hline $\begin{array}{l}\text { HEDPA } \\
\mathrm{NaSO}_{2} \mathrm{CH}_{2} \mathrm{OH} \\
\text { Details not ovailable } \\
\text { at this time }\end{array}$ & Not Effective & Not Effective & Not Effective & $\begin{array}{l}\text { Stated } \\
\text { Effective in } \\
\text { Secondary } \\
\text { Reference } \\
\text { Primary } \\
\text { Reference and } \\
\text { Details } \\
\text { Unavailable }\end{array}$ & $\begin{array}{l}\text { Effective as } \\
\text { Rinse Only }\end{array}$ & $\begin{array}{l}\text { Not } \\
\text { Effective }\end{array}$ & $\begin{array}{l}\text { Effective } \\
\text { as Rinse } \\
\text { Only }\end{array}$ & $\begin{array}{l}\text { Effective as } \\
\text { Rinse Only } \\
\text { Not Effective } \\
\text { for Infused } \\
\text { Nuclides }\end{array}$ \\
\hline
\end{tabular}


HNF-2917 Rev. 0

\subsection{REFRACTORY ACTINIDE DISSOLUTION BY CERATE ALTERNATIVE}

\subsubsection{Intended Application}

This process is considered principally for dissolving refractory actinide oxide compounds that are not mineralized with other elements. Therefore it should be best when residues of that type predominate.

\subsubsection{Effectiveness For Other Residue Forms}

The process is also very similar to the preferred process for removing actinides from the mixed-bed organic ion exchange resin (Dodd 1998), except of course in that process the cerate is used to displace the actinide from the anion resin, not to dissolve $\mathrm{PuO}_{2}$. If enough cerate is present, it can be expected to accomplish both tasks.

There is an implicit suggestion in the literature that cerate has some effectiveness towards actinides mineralized with silica, and also an inference that it may be effective against iron phases, because it has been found to successfully decontaminate stainless steel surfaces when applied electrochemically (Nikitina 1997a). The process is not expected to be effective towards other waste types except through its rinsing action.. It will tend to be consumed by the presence of organics, but shouldn't be consumed by other expected residue forms such as sand. 
HNF-2917 Rev. 0

3.1.3 Suggested Process Parameters

Cerate (from $\left.\left(\mathrm{NH}_{4}\right)_{2} \mathrm{Ce}\left(\mathrm{NO}_{3}\right)_{6}\right): 0.4 \mathrm{M}$

$\mathrm{HNO}_{3}: 6 \mathrm{M}$

Quantity: 2:1 Liquid to Residue by Volume

Agitate to suspend residue

Temperature: $60-90{ }^{\circ} \mathrm{C}$

Time: $2 \mathrm{hr}$.

Wash with same, rinse with water

Rinses to Neutralization

3.1.4 Discussion

Cerate ion is a convenient oxidizing agent in analytical chemistry, where one of its principal uses is in determining organic compounds by stoichiometrically oxidizing them at temperatures above $50^{\circ} \mathrm{C}$ (Kilbourn 1992) (Smith 1964). Its use in nuclear technology is Targely through its ability to dissolve large amounts of refractory $\mathrm{PuO}_{2}$ when applied electrochemically (Bray 1982) (Nikitina 1997a), where efficiencies of dissolution of large amounts of refractory $\mathrm{PuO}_{2}$ of $98 \%$ have been achieved. The cerate tends to defunctionalize anion exchange resin, and, as an anionic complex analogous to the plutonium, it displaces actinide anions from the same resins. It appears practical to use an excess of reagent for trace amounts of actinides instead of using an electrochemical cell.

3.2 SILVER-CATALYZED PERSULFATE OXIDATION OF REFRACTORY ACTINIDES ALTERNATIVE

\subsubsection{Intended App 1ication}

This process has been developed for dissolving refractory actinide oxides that are not mineralized with other elements (Fisher 1991) and hence is best applied when this type of residue predominates. 
HNF-2917 Rev. 0

\subsubsection{Effectiveness For Other Residue Forms}

This process may have some effectiveness towards actinides mineralized with silica, because it has been shown effective in recovering $\mathrm{Pu}$ from crucible slag, ashes and soils (Fisher, 1991) (Nikitina 1997a). But, it is not expected to be effective towards other waste types except through its rinsing action, though the sulfuric acid byproduct may be beneficial in dissolving iron oxide phases. The $\mathrm{S}_{2} \mathrm{O}_{8}^{2}$ reagent will tend to be consumed by the presence of organics at low temperature to a lesser extent than cerate. but i.t shouldn't be consumed by other expected residue forms such as sand.

\subsubsection{Suggested Process Parameters}

Persulfate (from $\mathrm{K}_{2} \mathrm{~S}_{2} \mathrm{O}_{8}$ ): $0.5 \mathrm{M}$

Silver (from $\mathrm{AgNO}_{3}$ ): $0.2 \mathrm{M}$

$\mathrm{HNO}_{3}: \quad 3 \mathrm{M}$

Quantity: 2:I Liquid to Residue by Volume

Agitate to suspend residue

Temperature: $25-40{ }^{\circ} \mathrm{C}$

Time: $2 \mathrm{hr}$.

Wash with Same, Rinse with Water;

Rinses to Neutralization

\subsubsection{Discussion}

Silver-catalyzed oxidation is normally applied electrochemically in nuclear technology to dissolve refractory $\mathrm{PuO}_{2}$ (Nikitina 1997) (Nikitina 1997a). It has a] so been studied electrochemically as an organic destruction agent (Smith 1997). It is a faster method at low temperatures than cerium (IV)-mediated electrochemical oxidation. It has been shown at Hanford that the electrochemical cell can be replaced by excess persulfate (Fisher 1991) to effectively dissolve large amounts of $\mathrm{PuO}_{2}$, or to recover $\mathrm{PuO}_{2}$ from scrap, soil or ash. Efficiencies of 89 to 100 percent have been seen for single contacts. A multiple contact experiment against fine soil has showm ca. 
HNF-2917 Rev. 0

$80 \%$ recovery per contact. This has also been demonstrated electrochemically in France (Nikitina 1997a), where the high silica content of the ash lends support to the idea that this process may help remove $\mathrm{Pu}$ from within a silica matrix. At higher temperatures, the reagents tend to be consumed by the oxidation of water. Hot, silver-catalyzed persulfate oxidation is one of two methods used at the 222-S labs for determination of total organic carbon (Schroeder 1997), however as an analytical method it gives poor recoveries for non-functionalized organics, and it has been observed to be ineffective at dissolving ion exchange resin beads.

\subsection{REFRACTORY ACTINIDES, SILICA-MINERALIZED ACTINIDES AND CESIUM- MINERALIZED ACTINIDES DISSOLUTION WITH NITRIC-HYDROFLUORIC ACIDS ALTERNATIVE}

\subsubsection{Intended Application}

This process is intended primarily for actinides and cesium contained within siliceous minerals, where the hydrofluoric acid can volatize the silicate or aluminosilicate minerals, leaving non-volatile radionuclides in solution. Because of the volatilization, the $\mathrm{SiF}_{4}$ offgas will have to be sparged through a dilute alkali solution and defluoridized by sequestration of fluoride with aluminum nitrate. The reagents are corrosive to equipment, and neutralization of the rinses will also have to include defluoridization with aluminum nitrate. A large amount of inert siliceous material in the residue may consume the HF without producing the desired decontamination, thus requiring replenishment of $\mathrm{HF}$ during the process.

\subsubsection{Effectiveness for Other Residue Forms}

The process is also traditionally used for dissolving refractory plutonium oxide (Nikitina 1997). In fact, a similar process is the recommended process for the AIDA/MOX 1 program in France (Bourges 1997). There is chemical inference that the process might work to free nuclides from iron minerals based on successful use of similar formulations as reactor piping decontamination agents (Schaller 1984) (Mertz 1996). 
HNF-2917 Rev. 0

\subsubsection{Suggested Process Parameters}

$\mathrm{HNO}_{3}: 6 \mathrm{M}$

HF: $\quad 0.3 M$

Quantity: 2:1 Liquid:Residue by Volume

Agitate to Suspend Residue

Temperature: $60-90{ }^{\circ} \mathrm{C}$

Time: $2 \mathrm{hr}$.

Sparge offgas through dilute alkali

Wash with Same

Rinse with Water

Rinses Combined with Sparge, then to Aluminum Fluoride Precipitation and Neutralization

\subsubsection{Discussion}

This process is based on a variety of traditional methods for dissolving refractory plutonium dioxide (Nikitina 1997), or for liberating radionuclides such as ${ }^{137} \mathrm{Cs}$ from siliceous materials. The silica is destroyed and silicon tends to volatize as $\mathrm{SiF}_{4}$, while the actinides remain non-volatile.

The reagent concentration choices suggested here are a compromise between effectiveness and corrosiveness towards the equipment. Traditional applications have varied widely in compositions. For example, to dissolve plutonium oxide or recover plutonium from scrap at PFP, the nitric acid concentration was normally $12 \mathrm{M}$ and the temperature was at the solution boiling point. Efficiencies of dissolution vary, depending on the pretreatment of the substrate and the concentration of reagents. In a most difficult case, without other additives such as $\mathrm{H}_{2} \mathrm{SO}_{4}, \mathrm{AgO}$ or $\mathrm{Ce}$ (IV), a boiling $12 \mathrm{M} \mathrm{HNO}_{3}, 0.1 \mathrm{MHF}$ mixture coufd achieve 50-54.2\% dissolution of $>1500^{\circ} \mathrm{C}$-calcined $\mathrm{PuO}_{2}$. If large amounts of inert siliceous materials are present in the residue, it may be necessary to replenish HF during the leaching process.

Nitric - hydrofluoric acids have been used as reactor piping or stainless steel decontamination reagents in the concentration range $0.8 \mathrm{M}$ nitric acid, $0.25 \mathrm{M}$ hydrofluoric 
acid (Schaller 1984). However, it was noted that radionuclides in iron oxide deposits are dislodged and made available for filtration to a greater extent than they are actually dissolved by these reagents. Here, we desire the radionuclides to be dissolved so that they may pass through the filter used to isolate the clean residue. Therefore the method may not be sufficiently effective against relatively large amounts of iron mineral deposits.

There is operational experience at PFP with the precipitation of silicates by sparging $\mathrm{SiF}_{4}$ through dilute alkali that shows the precipitation to be slow, and at times the precipitate can subsequently deposit on the equipment, clog small passages and otherwise be an annoyance (Barney 1998). The sparge should be arranged to minimize that annoyance.

\subsection{IRON DISSOLUTION BY CITROX ALTERNATIVE}

\subsubsection{Intended Application}

This assumes that dissolution of iron minerals will free the radionuclides from the residue. For a less corrosive form of iron oxide dissolution than the use of $\mathrm{HCl}$, this is a commercially available reactor decontamination technology that is compatible with TWRS acceptance -- a variation of the CITROX process (Serne 1996). Citric and oxalic acids totaling $6 \%$ of both reagents are stirred with the residue. The oxalic acid dissolves rust while the citric acid helps keep the iron in solution. The process may not be completely effective if refractory iron minerals such as goethite prove resistant to it. The neutralized rinses may be classified as complexant waste by TWRS acceptance criteria, which may complicate disposal to TWRS without an organic destruction treatment process.

\subsubsection{Effectiveness for Other Residue Forms}

The oxalic acid will also dissolve aluminum hydroxide. At the concentrations suggested, any liberated Pu(IV) should be complexed and held in solution by the oxalate, and not absorb onto anion exchange resin beads. The process is not expected to be effective against any other of the significant residue forms except as a rinse. 
HNF-2917 Rev. 0

\subsubsection{Suggested Process Parameters}

OxaTic Acid: $0.3 \mathrm{M}$

Citric Acid: $0.16 \mathrm{M}$

Quantity: 2:1 Liquid:Residue by Volume

Agitate to Suspend Residue

Temperature: $85-100^{\circ} \mathrm{C}$

Time: $2 \mathrm{hr}$.

Wash with Same

Rinse with Water

Rinses to Neutralization

\subsubsection{Discussion}

This would be the least corrosive towards process equipment of the iron-attacking processes considered. In normal commercial application, CITROX is applied in very dilute solution, being continuously circulated through a strongacid cation resin in the acid form to capture dissolved metal and regenerate the reagent. Here, we would substitute an excess of stirred reagents for the resin, and use enough solution to cover and suspend the residue. The efficiency of the process for iron-dissolution is hard to evaluate, because dislodged minerals available for filtration also result in decontamination. However, it can be said that the dilute reagents used in commercial practice transport several times their molar quantities of metals to the ion exchange resins. After filtering, washing and water rinsing the residue, the rinses are collected for neutralization. When combined with the nitric acid dissolution rinse, the result may become a complexant waste as defined by TWRS ( $\geq 10 \mathrm{~g} / \mathrm{L}$ TOC when evaporated to first precipitation). AW105 is not currently classified as a complexant concentrate (CC) waste tank, and therefore would not accept CC waste. If necessary to meet TWRS acceptance, the citric and oxalic acids could be destroyed by hydrogen peroxide in strong nitric acid solution before neutralization. The CITROX process has additional appeal because there is local commercial support for both this process (Serne 1996) (Newton 1998) and support for general process application to Hanford fuel storage basin desiudging (Schneidmilier 1998). 
HNF-2917 Rev. 0

However, there is some question whether the goethite will dissolve quickly enough, to be answered by simple lab testing for practical process operation.

\subsection{DISSOLUTION OF IRON MINERALS AND TRACE AMOUNTS OF NON-REFRACTORY ACTINIDES ALTERNATIVE}

\subsubsection{Intended Application}

This treatment assumes the radionuclides are locked in ironbased minerals. This method provides a large amount of acidic chloride to effectively complex iron. Major disadvantages are that this reagent is extremely corrosive for many metals of construction, and the chloride concentration would be unacceptable to TWRS without 30-fold dilution or a chloride-removal process.

\subsubsection{Effectiveness for Other Residue Forms}

This is not expected to be effective against any other of the significant residue forms except as a rinse.

\subsubsection{Suggested Process Parameters}

$\mathrm{HNO}_{3}: \quad 5 \mathrm{M}$

$\mathrm{HCl}: \quad 0.3 \mathrm{M}$

Quantity: 2:1 Liquid:Residue by Volume

Agitate to Suspend Residue

Temperature: $60^{\circ} \mathrm{C}$ - boiling

Time: $2 \mathrm{hr}$.

Wash with Same

Rinse with Water

Rinses to Chloride Removal and Neutralization 
HNF-2917 Rev, 0

\subsubsection{Discussion}

For iron minerals, reagents utilizing multi-molar concentrations of $\mathrm{HCl}$ are expected to provide analytically complete dissolution efficiency (Bock 1979). The method for dissolving non-refractory, loosely adherent radionuclides from KE basin sludge samples containing also iron-based minerals consisted of boiling $5 \mathrm{M} \mathrm{HNO}_{3}-5 \mathrm{M} \mathrm{HCl}-0.03 \mathrm{M} \mathrm{HF}$ (Bechtold 1994). Efficiencies varied among samples treated. For plutonium, dissolution efficiencies were from $>55 \%$ to $>99 \%$, while for iron, they were $>99.4 \%$. As used to dissolve similar actinides from soil samples in radiochemical laboratory practice, the nitric and hydrochloric acid concentrations are mixed as concentrated reagents (Catlow 1997). Those mixtures and the suggested process a11 approximate aqua regia, and therefore can be extremely corrosive even to noble metals. Therefore the concentrations actually suggested are a compromise between effectiveness against the small amounts of iron mineral to be dissolved and corrosiveness towards the equipment. The need for chloride removal from the rinses may be met by a cerate-mediated electrochemical oxidation of chloride to $\mathrm{Cl}_{2}$ gas (Koehly 1993).

Overall, this alternative is not attractive, because the extent of compromise away from the usual practice for dissolving iron is great, while the corrosiveness is still problematical.

\subsection{DISSOLUTION OF ZIRCALOY PIECES BY ZIRFLEX CLADDING DISSOLVER SOLUTION ALTERNATIVE}

\subsubsection{Intended Application}

If the residue includes Zircaloy particles or pieces which themselves contain infused radionuclides that drive the overall residue above ERDF acceptance limits, then the PUREX cladding dissolution process can dissolve the Zircaloy and free the radionuclides. The Zirflex process normally uses at least $0.4 \mathrm{M}$ nitrate ion or $90 \mathrm{mg} / \mathrm{L}$ ferric ion to minimize hydrogen evolution, and perhaps an air or steam sparge to remove generated ammonia and maintain desired $\mathrm{pH}$. otherwise it is straightforward (Westinghouse 1989) and shouldn't require verification testing. The rinses may be defluoridized with aluminum nitrate before neutralization. 
HNF-2917 Rev. 0

\subsubsection{Effectiveness for 0ther Residue Forms}

This process is not expected to be effective against any other of the significant residue waste forms except as a rinse.

\subsubsection{Suggested Process Parameters}

$\mathrm{NH}_{4} \mathrm{~F}: \quad 5.3 \mathrm{M}$

$\mathrm{NH}_{4} \mathrm{NO}_{3}: 0.5 \mathrm{M}$

Quantity: 2:1 Liquid:Solid by Volume or sufficient liquid to assure $6: 1 \mathrm{~F}^{-}: \mathrm{Zr}$, whichever is greater

Agitate to Suspend SoTids

Steam Sparge/Offgas Hydrogen and Ammonia

Time: $6 \mathrm{hr}$.

Temperature: Boiling

Rinse with boiling water before cooling

Rinses to Defluoridization and Neutralization

\subsubsection{Discussion}

With the depletion of ammonium ion as volatile ammonia while reaction progresses, a desirable free fluoride ion concentration of $6 \mathrm{M}$ provides an $80 \mathrm{mil} / \mathrm{hr}$ dissolution rate, which over 6 hours should dissolve the cladding pieces and their infused actinides with $100 \%$ efficiency. The assurance of $6: 1$ fluoride:zirconium and the rinse step are meant to prevent precipitation of zirconium before filtration. The hydrogen and ammonia offgases can be an explosion hazard if they are not safely handled Verification testing is probably unnecessary for such a well-established treatment. Only production testing of fluoride addition may be necessary to counter any possible fluoride consumption by sand or soil in the residue. 
HNF-2917 Rev. 0

3.7 DISSOLUTION OF GOETHITE BY HEDPA AND REDUCING AGENT ALTERNATIVE

\subsubsection{Intended Application}

This process is explicitly called out in a secondary reference (Schulz 1991) as being effective in dissolving goethite. The HEDPA in the form of an alkylphosphonic acid mixture is commercially available under the trade name IONQUEST 201. Together with the reducing agent sodjum formaldehydesulfoxylate it dissolves goethite, and is later easily destroyed, leaving phosphate, sulfate and carbon dioxide. The sulfate and phosphate are not desirable in vitrification feeds, though small quantities may not be unacceptably offensive.

\subsubsection{Effectiveness for Other Residue Forms}

The HEDPA process is not expected to be effective against any other of the significant residue forms.

\subsubsection{Suggested Process Steps}

The details of the process are not known at this time.

\subsubsection{Discussion}

The attraction of this process is the claim of its direct effectiveness against goethite, an identified mineral in the canister sludge residuals that themselves are above TRU levels. Also attractive is the ability to destroy the reagents by digestion in $\mathrm{HNO}_{3}$ or $\mathrm{HNO}_{3}-\mathrm{H}_{2} \mathrm{O}_{2}$ solutions. This destruction could be accomplished by adding the rinses to the nitric acid dissolution rinse and digesting before neutralization.

This process will not be recommended, however, because exact details have not been found. It will remain a possibility to be investigated further only if it is determined that complete dissolution of goethite is necessary and is unachievable by any other recommended process. 
HNF-2917 Rev. 0

4.0 PROCESS SELECTION and IMPLEMENTATION

\subsection{Speciation}

The first matter in selecting the processes will be to speciate the actinides and cesium in the residues, in order to justify or rule out the need for any of the proposed process steps.

4.2 Testing and Optimization

The proposed process conditions should be tested for efficacy, with the exception of the Zirflex process, and the suggested process parameters optimized. There is also a little flexibility among the processes for combining them. For example, there may be an acceptable combination of $\left.\mathrm{HNO}_{3}-\mathrm{HC}\right]$ - HF not considered above that might prove to be optimally effective as a single process. However, the flexibility for combining alternatives is limited in general. Consideration should be made to selecting lined vessels and equipment for the processes to eliminate corrosion problems, especially for chloride or fluoride-bearing reagents.

\subsection{Prioritization}

The following order of priorities is followed for selecting a process or processes:

4.3.1 Known effectiveness in releasing the TRU content from the most likely residue type.

\subsubsection{Compatibility with TWRS acceptance}

\subsubsection{Compatibility with ERDF acceptance}

4.3.4 Operational Complexity:

4.3.4.1 Corrosivity requiring special equipment

4.3.4.2 Requirements for secondary waste management

\subsection{PROCESS RECOMMENDATIONS}

The bases for recommending leaching processes are likely to change rapidly as more is learned about the nature of the residuals from canister sludge dissolution tests. At this time we expect the largest volume of sludge will contain a major proportion of inert minerals such as sand and other soil components, and a smaller proportion of fuel 
HNF-2917 Rev. 0

corrosion products. On that basis, the following order of choices for testing is presented:

5.1 The Cerate process is the first choice due to its broad effectiveness for actinides in refractory oxide form, and in organic ion exchange resin beads, as well as less certain effectiveness for actinides in active siliceous materials. It should not be consumed uselessly by inert minerals except organic detritus. The process will not require complex secondary waste treatment.

5.2 The Persulfate-Silver process is the second choice due to the same general effectiveness as the cerate process except for its lack of effectiveness against the ion exchange resin beads. It also will not be consumed uselessly by inert minerals or organic detritus. Neutralization of rinses may need to be preceded by a reductant step to destroy excess persulfate.

5.3 The Nitric-Hydrofluoric Acid process is the third choice. It is traditionally effective against refractory actinides and the major portion of problematical residues, i.e., siliceous materials. It also has been successfully used to decontaminate ferrous metals. The HF may need to be replenished during processing due to consumption by inert minerals, and offgas treatment is required. It is also more corrosive than the previous choices.

5.4 A variation of the CITROX process is next suggested, if the other processes don't work, and/or the actinides are found to be residing in iron-bearing or aluminum-bearing minerals. It is the least corrosive against ferrous metals of the processes used to dissolve iron minerals.

5.5 The Nitric-Hydrochloric Acid process is the last general process to recommend, because of its 1 imited generality of effectiveness, the extent of compromise to reduce its extreme corrosivity, and the need to somehow remove the waste chloride.

5.6 The Zirflex process is recommended only for the special case when Zircaloy particles are found to be the carrier of TRU leve] actinides in the residue. It requires some sparging and concentration control during processing, as well as flammable offgas treatment. 
HNF-2917 Rev. 0

\subsection{REFERENCES}

Barney, G. S., Private Communication, June, 1998.

Bechtold, D. B., 1994, Report of Laboratory Test Plan for analysis of KE Basin Backwash Pit Samp7es, WHC-SD-NR-TRP-021, Revision 0, Westinghouse Hanford Company, Richland, Washington, 1994.

Bechtold, D. B., 1981, KE Fuel Storage Basin Activity Mapping in Support of Exposure Reduction, UNI-1697, UNC Nuclear Industries, Incorporated, Richland, Washington, 1981.

Bourges, J., 1997, AIDA/MOX 1 Program, Presentation, Numatec Hanford Corporation, Richland, Washington, August 20, 1997.

Bray, L. A. and J. L. Ryan, 1982, "Catalyzed electrolytic Dissolution of Plutonium Dioxide", In Actinide Recovery from Waste and Low-Grade sources, eds. J. D. Navratil and W. W. Schulz, Harwood Academic Publishers, London, United Kingdom, 1982, 129-154.

Bock, R., 1979, A Handbook of Decomposition Methods in Analytical Chemistry, International Textbook Company, Glasgow, New Zealand, 1979.

Burns, P. C. et a7. 1997, Incorporation Mechanisms of Actinide elements into the Structures of $u^{\text {ot }}$ Phases Formed during the Oxidation of Spent Nuclear Fuel, Journal of Nuclear Materials, Vol. 245, No. 1, pg. 1-9, May 1997.

Byers, K. R., 1974, Total Dissolution of Soi7 Prior to Radiochemical Determinations, LA-549-135 (formerly KFFUSE-01A), At lantic Richfield Hanford Company, Richland, Washington, 1974.

Carlson C. D., 1998, untitled draft of $\mathrm{K}$ basin sludge dissolution test report, Pacific Northwest Laboratory, Richland, Washington, June 8, 1998.

CatTow, S. A., 1997, Nitric Acid - Hydrochloric Acid Leach of Soil, LA-544101, Revision C-1, Numatec Hanford Corporation, Richland, Washington, 1997.

Corriveau, C. E., 1996. Environmental Restoration Disposal Facility Waste Acceptance Criteria (ERDF), BHI-00139, Rev 2, Table 4-1, February, 1996

de Lamartinie, L., 1998, Personal Communication to J. Bourges, July 13, 1998.

Dodd, D. A., 1998, Engineering Study, Removal of Radionuclides from Organic Ion Exchange Resin in $K$ Basin Sludge, HNF-2802, Numatec Hanford Corp., Richland, Washington, 1998.

Flament, T. A., Testing Strategy to Support the Development of $K$ Basin Sludge Treatment Process, HNF-2574, Numatec Hanford Corporation, Richland, Washington, Apri1 16, 1998. 
HNF-2917 Rev. 0

Flament, T. A., 1998a, Personal Communication to D. B. Bechtold, July 13, 1998.

Fisher, F. D. et al., 1991, Silver-Catalyzed $\mathrm{PuO}_{2}$ Dissolution with Persulfate, WHC-SA-1170, Westinghouse Hanford Company, Richlând, Washington, June 1991.

Eberly, P. 0. et al., 1996, Clays at the Natural Nuclear-Reactor at Bangombe, Gabon - Migration of Actinides, Radiochimica Acta, Vol. 74, pp 271-275, 1996.

Fowler, K. D., 1995, Tank Farm Waste Transfer Compatibility Program, WHC-SDWM-OCD-015, Revision 1, Lockheed Martin Hanford Corp., Richland, Washington, 1995.

Hashke, J. M., 1995, Reactions of Plutonium and Uranium with Water: Kinetics and Potential Hazards, LA-13069-MS, Los Alamos National Laboratory, Los Al amos, New Mexico, 1995.

Hashke, J. M., 1990, The P7utonium-0xygen Phase Diagram, LA-UR-90-2567, Los Al amos National Laboratory, Los Alamos, New Mexico, 1990.

Hoefer, V. L., 1997, Personal Communication to D. R. Precechte], November 25, 1997.

Kilbourn, B. T., 1992, Cerium, a Guide to Its Role in Chemical Technology, Molycorp, Inc., White Plains, New York, 1992.

Koehly, G., et al., 1993, Décontamination de Déchets Solides Contaminés en Émetteurs A7pha et Récupération du P7utonium, EUR 1446 FR, Commission des CommunautÉs Européennes, Luxembourg, 1993.

Krot, N. N., Study of Solid State Transformations of Pu(IV) Hydrous Oxide Precipitates in A7kaline Media Under conditions Modeling Long-Term Storage of Hanford Plant Wastes, presentation, Institute of Physical Chemistry, Russian Academy of Sciences, Moscow, Russian Federation, March, 1998.

Makenas, B. J., et al. 1998. Analysis of Sludge from Hanford $K$ West Basin Canisters, HNF-1728, DE\&S Hanford, Inc., Richland, Washington, February, 1998.

Makenas, B. J., et a]. 1997. Analysis of S7udge from Hanford K East Basin Canisters, HNF-SP-1201, DE\&S Hanford, Inc., Richland, Washington, September 1997.

Makenas, B. J., et a7. 1996. Analysis of S7udge from Hanford K East Basin Floor and Weasel Pit, WHC-SP-1182, Westinghouse Hanford Company, Richland, Washington, April 1996. 
HNF-2917 Rev. 0

Mertz, C, et a1., 1996, Decontamination of Actinides and Fission Products from Stainless Steel Surfaces, paper given at the American Nuclear Society topical meeting on decontamination and decommissioning, Chicago, 1996, Argonne Nationat Lab, Argonne, Illinois.

Newton, P., PN Services, Inc., Richland Washington, private communication, June $4,1998$.

Nikitina, G. P., et a1., 1997, Existing Methods for Dissolution of Plutonium Dioxide. I. Dissolution in Mineral Acids and Their Mixtures, Radiochemistry, Vol. 39, No. 1, 1997, pp. 12-25, translated from Radiokhimiya, Vol 39, No. 1, 1997, pp. 14-27.

Nikitina, G. P., et al., 1997a, Existing Methods for Dissolution of Plutonium Dioxide. II. Redox Dissolution of Plutonium dioxide with the Use of Homogeneous Catalysts, Radiochemistry, Vol. 39, No. 2, 1997, pp. 109-122, translated from Radiokhimiya, Vol 39, No. 2, 1997 pp. 112-126.

Pearce, K. L., 1998. Data Quality Objectives for $K$ Basin Conditioning System Laboratory Testing, HNF-1927, Rev. 1, Numatec Hanford Corporation, Richland Washington, February, 1998.

Serne, R. J. et a1., 1996, Characterization of Radionuclide-Chelating Agent Complexes Found in Low-Level Radioactive Decontamination Waste, Literature Review, NUREG/CR-6124, PNL-8856, Pacific Northwest Laboratory, Rich1 and, Washington, March, 1996.

Schaller, K. H. and B. Huber, Ed., 1984, Decommissioning of Nuclear Power Plants, Proceedings of a European Conference Held in Luxembourg, 22-24 May 1984, Graham \& Trotman Ltd., London, 1984, pg. $142 \mathrm{ff}$.

Schneidmiller, D., 1998, Private communication, June 8,1998.

Schroeder, R. W., 1997, Determination of Carbon by Hot Persulfate Oxidation and Coulometric Detection, LA-342-100, Waste Management Hanford Corporation, Richland, Washington, December, 1997.

Schulz, W. W., M. J. Kupfer, 1991, Candidate Reagents and Procedures for the Dissolution of Hanford Site Single-Shell Tank Sludges, WHC-EP-0451 October, 1991.

Smith, G. F., 1964, Cerate Oxidimetry: Further Applications in the Use of Cerium in Volumetric Analysis, 2nd Ed., G. Frederick Smith Chemical Company, Columbus, Ohio, 1964.

Smith, W. H., G. M. Purdy, S. D. McKee, 1997, Comparison of Silver(II), Cobalt(III), and Cerium(IV) as Electron Transfer Mediators in the MEO Mixed Waste Treatment Process, Los Alamos National Laboratory, Presented at the I7EC Symposium, American Chemical Society, Pittsburgh, PA. 
HNF-2917 Rev. 0

Swanson, J. L., et a1., 1985, Laboratory Studies of Shear/Leach Processing of Zircaloy Clad Metal7ic Uranium Reactor Fuel, PNL-5708, Pacific Northwest National Laboratory, Richland, Washington, December, 1985.

Thomason, H. P. and S. J. Williams, 1992, Near-Field Solubility Studies, NSS/R128, AEA-D\&R-0068, Harwe1T Laboratory, Oxfordshire, United Kingdom, February, 1992.

Weakley, E. A., 1979, Fuels Engineering Technical Handbook, UNI-M-61, UNC Nuclear Industries, Inc., Richland, Washington, Apri1, 1979.

Westinghouse Hanford Company, 1988, N Reactor Updated Safety Analysis Report, WHC-SP-0297, Volume 3, Westinghouse Hanford Company, Richland, Washington, 1988.

Westinghouse Hanford Company, 1989, PUREX Technical Manual, WHC-SP-0479, Westinghouse Hanford Company, Richland, Washington, 1989. 


\section{DISTRIBUTION SHEET}

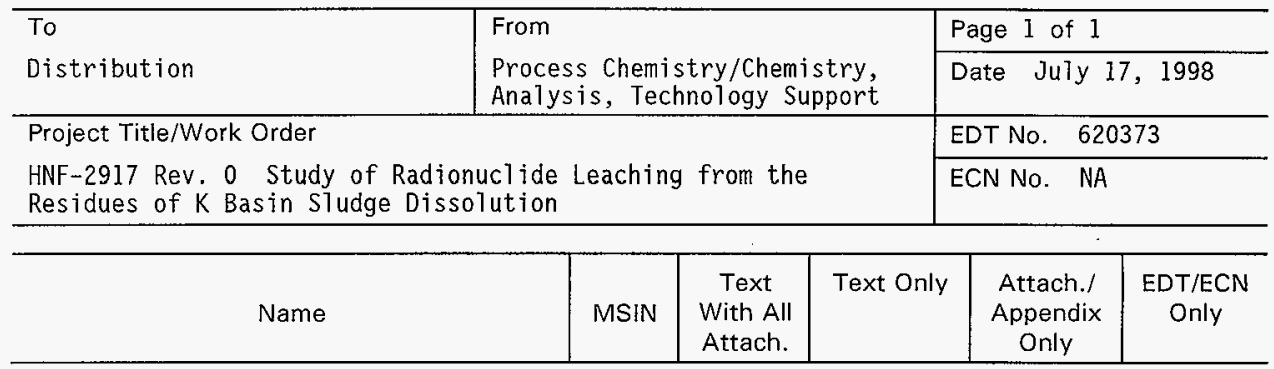

\section{B\&W Hanford Corporation}
A. G. Westra
R3-86
$X$

Fluor Daniel Hanford. Inc.

M. J. Wiemers

R3-11 X

Lockheed Martin Services, Inc.

Central Files

SNF Projects File

Numatec Hanford Corporation

D. B. Bechtold

M. A. Beck

J. Y. Bourges

D. A. Dodd

T. A. Flament

J. R. Jewett

L. L. Lockard

L. L. Lockrem

W. C. Miller

W. W. Rutherford

W. I. Winters
B1-07

R3-11

$x$

$X$

T6-07

T6-07

T6-07

T6-50

$\mathrm{H} 7-20$

T6-07

S3-90

S3-90

T6-50

H7-20

T6-50
$X$
$X$
$X$
$X$
$X$
$X$
$X$
$X$
$X$
$X$
$X$

Pacific Northwest National Laboratory

C. H. Delegard

P7-25

K. L. Silvers

K9-08

$X$
$X$ 